\author{
남후선 $^{1)} \cdot$ 김순영 ${ }^{2) \uparrow}$ \\ ${ }^{1)}$ 대경대학교 패션스페셜리스트과 \\ 2)건국대학교 의상디자인 전공
}

\title{
A Study on the Court Dance Garments of the Jangsaengboyeonjimu, Yeonbaekbokjimu, Jesuchang, and Choehwamu
}

\author{
Hoo Sun Nam ${ }^{1)}$ and Soon Young Kim $\left.{ }^{2}\right)^{\dagger}$ \\ ${ }^{1)}$ Dept. of Fashion Specialist, Taekyung College; Gyeongsan, Korea \\ ${ }^{2)}$ Dept. of Apparel Design, Konkuk University; Seoul, Korea
}

\begin{abstract}
This study explores the types, shapes and changes of the court dance garments of mudong[child court dancer] and yeoryeong[female court dancer] for court dances such as Jangsaengboyeonjimu, Yeonbaekbokjimu, Jesuchang, and Choehwamu, and the arrangement of colors in their garments. The conclusion of the study is as follows: First, the type of garments of mudong varied according to the type of dance, role of mudong and passage of time. In all four jeongjae's, hongpo[red robe] and baekjilheukseonjungdaneui[white under garment trimmed in black] were commonly found. Second, the dress of yeoryeong in the Jangsaengboyeonjimu, Yeonbaekbokjimu, Jesuchang and Choehwamu was that of other yeoryeong, which was basically comprised of hwagwan[flower headdress], hwangchosam[yellow robe], hongchosang[red skirt] and sudae[embroidered belt]. Third, the color schemes of the court dance garments used in Jangsaengboyeonjimu, Yeonbaekbokjimu, Jesuchang and Choehwamu revealed that the color arrangement of sangsaeng [mutual generation] of the Ohaeng[Five Elements] scheme were favored in the garments of mudong and yeoryeong. The dress of mudong is characterized by sangsaeng between top and bottom, and between total and part, while the color scheme of the outer and inner was sanggeuk[mutual overcoming]. As for yeoryeong, the color arrangement was of sangsaeng in top and bottom, outer and inner, and total and part, but in the five-colored hansam[sleeve extension], both sangsaeng and sanggeuk were found.
\end{abstract}

Key words: court dance garment(궁중무용복식), Jangsaengboyeonjimu(장생 보연지무), Yeonbaekbokjimu(연 백 복지무), Jesuchang(제수창), Choehwamu(최화무)

\section{1. 서 론}

본 연구는 장생보연지무(長生寶宴之舞), 연백복지무(演百福之 舞), 제수창(帝壽昌), 최화무(催花舞) 복식의 종류 및 형태, 변 화 특징을 이해하고, 이들 복식에 사용된 색채의 배색 특성을 고찰한 연구이다. 이들 4 개의 궁중 무용은 모두 19세기 초에 새롭게 창제된 당악 정재로서, 20세기 초까지 연행되었던 것들 이다. 현재는 창덕궁, 경복궁, 운현궁 등에서 재현되는 궁중 무 용 가운데 일부가 전승되고 있다.

지금까지 궁중 무용 복식에 관한 연구가 많이 행해져 왔으 나 이들은 대체로 특정 시기에 편찬된 하나의 의궤를 분석 대 상으로 하거나, 하나의 정재 복식에 대한 통시적 고찰이 주를 이루어 왔다. 필자는 지난 십 여간 유사한 성격을 지니는 정재

$\dagger$ Corresponding author; Soon Young Kim

Tel. +82-2-450-3779, Fax. +82-2-444-1058

E-mail: soonyoung1.kim@gmail.com
들을 함께 묶어 형태와 색채를 분석해 왔으며(Nam, 2000; Nam, 2003; Nam \& Kim, 2005; Nam \& Kim, 2006), 본 연구는 이러한 일련의 연구 가운데 하나에 해당한다. 유사한 성 격의 정재 복식을 함께 묶어 분석해 보는 것은 형태와 색채가 동일하거나 유사한 것이 많은 정재 복식의 성격을 고려할 때 효율적인 연구 방법이 될 수 있다. 본 연구는 19세기에 새롭게 창제된 당악 정재 복식에 관한 연구이다. 연구의 결과는 19세 기 당악 정재 복식의 고증 제작을 위한 기초 자료가 될 수 있 으며, 오행의 원리가 실제 궁중 무용 복색에 어떻게 적용되었 는지를 이해하는데 도움이 될 것으로 생각된다.

구체적 연구 문제는 다음과 같다. 첫째, 장생보연지무, 연백 복지무, 제수창, 최화무 무동 및 여령 복식의 종류와 형태를 살 펴보고, 시간의 흐름에 따른 변화 특징을 파악한다. 둘째, 오행 의 상생상극관계에 의거하여 무동 및 여령 복식의 배색 관계를 분석한다. 본 연구는 문헌 연구로서, 연구에 이용된 자료는 『純祖戊子進爵儀軌(Sunjo Muja Jinjak Uigwe)」(1828), 『純祖 
己丑進餾儀軌(Sunjo Gichuk Jinchan Uigwe)」(1829)，『憲宗戊 申進饌儀軌(Heonjong Musin Jinchan Uigwe)」(1848)，『高宗丁 亥進饌儀軌(Gojong Jeonghae Jinchan Uigwe)』(1887), 『高宗壬 辰進餃儀軌(Gojong Imjin Jinchan Uigwe)」(1892)，『高宗壬寅 進宴儀軌(Gojong Imin Jinyeon Uigwe)』(1902) 등이다. 문헌과 더불어 정재도를 볼 수 있는 채색 자료로써 국립중앙박물관 소 장 기축진찬도(1829), 무신진찬도(1848), 정해진찬도(1887), 연 세대학교 박물관 소장 광무 5년(1901) 신축진연도 등에 나타난 정재 복식을 분석하였다.

\section{2. 장생보연지무, 연백복지무, 제수창, 최화무의 유래와 특징}

장생보연지무, 연백복지무, 제수창, 최화무는 모두 19세기 초, 순조 때에 창작된 당악정재이다. 순조조는 한국의 궁중무용이 가 장 화려하게 꽃피운 시기로서, 이 시기 궁중무용에서 주목되는 것은 효명세자의 성심과 전악(典樂) 김창하의 열성으로 상당수 의 궁중무용이 창작된다는 점이다(Heo, 2005). 이 시기에 창작 된 정재는 가인전목단, 경풍도, 고구려무, 만수무, 사선무, 춘앵 전 등 대부분 향악정재였다(Heo, 2005). 향악정재는 고려 이전 시대로부터 전승된 전통 음악에 맞추어 추는 춤으로, 우리말로 된 노래를 부르며, 죽간자의 인도가 없고, 춤의 시작과 끝에 절 을 하는 형식이다(Seong, 1995). 그런데 장생보연지무, 연백복 지무, 제수창, 최화무는 모두 '죽간자'와 '구호' 등의 형식을 갖 춘 당악정재를 표방한 정재들이다. 당악정재는 한문으로 된 창 사(唱詞)를 죽간자와 무원이 부르며, 춤이 시작하자마자 두 명 의 죽간자의 인도로 무용수들이 들어오고 춤이 끝나면 곧 바로 나가는 형식이다(Seong, 1995). 장생보연지무, 연백복지무, 제 수창, 최화무는 비록 당악정재를 표방했지만, 실제로 반주음악 은 '향당교주'를 사용했다(Heo, 2005). 즉, 이들 정재는 비록 당악형식이었지만, 민족미감의 향유가 중시되었던 추세에 따라 향악과 당악의 경계선이 모호해진 시대의 대표적 당악정재로 이해할 수 있다(Heo, 2005).

장생보연지무는 임금의 만수무강과 국가의 복을 기원하는 내 용의 춤이다(Nam, 1995). 장생보연지무는 불교와 연관된 춤으 로 여겨지기도 하는데, 이는 장생보연지무 기록이 있는 각 의 궤의 의주(儀註)에 '장생보연지무보살만(長生寶宴之舞菩薩蠻)'이 라는 기록이 있기 때문이다(Lee \& Son, 2010a). 불교에서 '보살 (菩薩)'은 부처의 다음 가는 사람을 지칭하며, '만(蠻)'은 한족과 는 다른 종족을 말한다(Lee \& Son, 2010a). 문헌에 장생보연지 무의 기록이 처음 등장하는 시기는 순조 29년(1829)으로『기 축진찬의궤』에 보인다. 『기축진찬의궤』 정재악장의 기록에 따르면, 장생보연지무는 “여기(女妓) 2 인이 죽간자를 받들고 좌 우에 나눠 서고, 1 인은 앞에, 1 인은 중앙에, 1 인은 뒤에, 1 인은 좌측에, 1 인은 우측에 자리하여, 서로 바꿔가며 춤춘다.”라고 하였다. 이 정재의 특징으로는 제 1 변에서 제9변까지의 변화가
다양함을 꼽을 수 있다. 제1변 상대무(相對舞), 제2변 수수무(垂 手舞), 제 3 변 상배무(相背舞), 제4변 산작화무(散作花舞), 제 5 변 수 수무(垂手舞), 제6변 오방무(五方舞), 제7변 염수무(斂手舞), 제8 변 사선무(四仙舞), 제9변 염수무로 구성된다(National Gugak Center, 1981). 고종 30년(1893)『계사년홀기』를 비롯하여 광 무 5년(1901)『신축외진연홀기』, 『신축진연홀기』, 『신축무동 홀기』, 『신축진찬홀기』, 『신축진찬익일회작홀기』, 『신축여 령홀기』에 장생보연지무 정재의 진행 순서가 전해진다(Lee \& Son, 2010a).

연백복지무는 온갖 복을 펼치는 내용의 긴 창사를 부르는 것 이 중심을 차지하는 정재이다. 다른 춤에 비하여 창사가 많은 것이 특징이다(Lee \& Son, 2010a). 순조 29년(1829) 『기축진 찬의궤』에 처음으로 기록이 보인다. 『기축진찬의궤』 정재악 장에 따르면, "무동 2 인은 죽간자를 받들고 동서로 나눠서고, 4 인은 뒤에 자리하여 한 줄로 서며, 1 인은 그 뒤를 따르는데, 모 두 북향하여 서로 바꿔가며 춤춘다.”라고 하였다. 고종 30 년 (1893)『계사년홀기』, 광무 5년(1901) 『신축외진연홀기』, 『신 축진연홀기』, 『신축여령홀기』, 『신축무동홀기』에 연백복지무 정재의 진행 순서가 전해진다(Lee \& Son, 2010a).

제수창은 임금이 덕이 높아 상제께서 장수로 보답하여 창성 하게 한다는 내용의 정재이다. 순조 28년(1828) 자경전 진작 때 임시로 지었던 '제수창지곡(帝壽昌之曲)'에 효명세자가 죽간 자 구호와 치어(致語)를 만들어 창(唱)하여 순조 29년(1889) 6 월 19일 대전진찬에서 처음 사용되었다(Lee \& Son, 2010b). 『기축진찬의궤』정재악장의 기록에 따르면, “무동 2 인은 죽간 자를 받들고, 1 인은 족자(族子)를 받들고 앞으로 나아가 벌려 선다. 4 인은 두 줄로 나뉘어 사방에 서며, 1 인은 중앙에 자리 한다. 1 인은 황개(黃蓋)를 받들고 뒤따른다. 또 4 인은 그 뒤에 위치하여 벌려 선다. 모두 북향하여 춤춘다.”라고 하였다. 『계 사년홀기』, 『신축진연홀기』, 『신축무동홀기』에 제수창 정재 의 진행 순서가 기록되어 있다.

최화무는 꽃피기를 재촉하고, 봄이 오기를 고대하는 내용의 정재이다. 문헌에 최화무의 기록이 처음 등장하는 시기는 순조 28년(1828)으로 『무자진작의궤』에 나타난다. 최화무 협무창사 중 4번째의 금도초전사(金刀初剪詞) 부분은 육화대(六花豚)의 삼념시(三念詩)가 그대로 쓰였고, 죽간자의 후구호도 육화대의 죽간자 후구호를 기본으로 하여 수정하여 사용하였다(Lee \& Son, 2010c). 『무자진작의궤』부편에「도서집성(圖書集成)」 을 인용하여, “송나라 태종(太宗)이 친히 창제한 소석조(小石調) 아홉 번째가 최화발(催花發)이다. 무동 6 인이 나란히 서서 북향 하여 춤춘다.”라고 되어 있다. 그런데 『기축진찬의궤』부편에 서는 “무동 2 인이 죽간자를 들고 앞에서 나란히 서고, 1 인은 그 뒤에서 북향하여 춤춘다."라고 기록되어 있음을 볼 때, 순 조 29년(1829)에 춤의 형식이 약간 고쳐졌던 것으로 보인다. 『계사년홀기』, 『갑오외진연홀기』, 『신축진찬홀기』에 최화무 정재의 진행순서가 기록되어 있다(Lee \& Son, 2010c). 


\section{3. 장생보연지무, 연백복지무, 제수창, 최화무 복식의 종류 및 형태}

\section{1. 장생보연지무(長生寶宴之舞)}

순조 29년(1829) 『기축진찬의궤』는 효명세자가 순조의 40 세 생일을 기념하여 올린 2차례(2월과 6월)의 연향에 대한 기 록이다(Kim, 2007). 장생보연지무는 이 연향의 외연과 내연에 서 모두 거행되었다. Fig. 1은 『기축진찬의궤』 권수 정재도 에 전하는 장생보연지무로 외연에서는 무동이, 내연에서는 여 령이 춤을 추고 있다. 오른쪽의 여령 정재도에서 죽간자 아래 에서 춤을 추는 5 인 여령의 춤사위는 국립중앙박물관 소장 1829년 기축진찬도(유물번호: 덕1665) (Natinoal Museum of Korea, 2010)에 보이는 것과 동일하다(Fig. 2). Fig. 1에서 앞 의 2 인은 죽간자(竹竿子)를 들고 있고 나머지 5 인은 춤을 추고 있다. 죽간자는 붉은 칠을 한 나무 자루 위에 세죽(細竹) 100 여개를 꽂고 붉은 실로 엮은 후 금박한 수정 구슬을 달아서 장식한 의물인데, 『기축진찬의궤』에 그려진 장생보연지무 죽 간자의 형상은 Fig. 3 과 같다.

무동 복식에 관해서는 『기축진찬의궤』권3 부편 공령조에 “무애, 최화무, 가인전목단, 장생보연지무의 무동은 각건, 홍포, 백질흑선중단의, 남야대, 흑화를 착용한다."고 기록되어 있으며, 권수 복식도에 그려진 무동 복식의 형태는 Fig. 4와 같다. 각건 은 앞이 낮고 뒤로 갈수록 높아지는 경사진 사면이 있는 복두 와 같은 형태이다. 홍포는 대수 단령포의 형태이며, 백질흑선중 단의는 깃, 수구, 도련에 선이 둘러진 동정 달린 직선 깃의 포 형태이다. 복식도에는 전악의 은야대(銀也帶)가 그려져 있으나, 우측에 있는 ‘금동홍남야대동(金銅紅藍也帶同)’이라는 기록으로 볼 때 남야대도 동일한 형태였음을 알 수 있다. 야대는 '야자 대(也字帶)'라고도 하는데, 대의 한쪽 끝이 아래로 늘어져 한문 글자의 '也'자 형상이 된다고 하여 붙여진 이름이다(Heonjong Musin Jinchan Uigwe, 2006). 흑화는 전악, 악공, 무동의 것이
동일하다.

『기축진찬의궤』에서 장생보연지무 여령 복식에 관한 기록 이 별도로 없는 것으로 보아 장생보연지무 여령의 복식은 일반 여령의 복식을 따랐음을 수 있다. 『기축진찬의궤』 권3 부편 공령에서 “각무정재여령은 화관(花冠)을 쓰고, 초록단의(草綠丹 衣), 황초단삼(黃單衫), 이남색상표홍초상(裏藍色裳表紅裳), 홍단 금루수대(紅緞金鏤繡帶), 오채한삼(五彩汗衫), 초록혜(草綠鞋)를 착용한다."고 기록되어 있다. Fig. 5와 같이 복식도에서는 일반 여령의 화관, 황초삼, 홍초상(또는 황초상), 오색한삼, 수대가 그 려져 있다(Fig. 5). 화관은 높은 원통형 모자 위에 꽃이 달린 형상이며, 황초삼은 동정 달린 합임의 반소매 옷으로 양 옆과 뒤 중심에 트임이 있다. 홍초상은 무릎을 가릴 정도 길이의 앞 치마 형태이며 옆선이 곡선적이다. 오색 한삼은 손목에 끼울 수 있도록 되어 있으며 수대에는 5 개의 한자어가 수놓아져 있다. 1895 년 정조의 화성 행차 기록인 『원행을묘정리의궤』의 도설 부분을 채색 필사한 화첩 원행정리의궤도(유물번호: 신 201)(National Museum of Korea, 2012)에 그려진 여령 복식의 형태와 비교해 볼 때 큰 차이가 없으나, 다만 황초삼의 소매 배래가 직배래에서 곡선배래로 바뀐 것이 눈에 띈다(Fig. 6).

Fig. 7은 헌종 14년(1848) 『무신진찬의궤』권수 정재도에 전하는 여령의 장춘보연지무이다. 동일한 춤사위가 국립중앙박 물관 소장 1848년 무신진찬도(유물번호: 본13243)(National Museum of Korea, 2010)에 그려져 있다(Fig. 8). 『무신진찬 의궤』는 순원왕후(1789-1857)의 육순을 경축하여 베푼 연향에 대한 기록으로(Kim, 2004), 이 의궤 정재도에 전하는 장춘보연 지무는 고종 24년(1887) 『정해진찬의궤』정재도 및 국립중앙 박물관 소장 1887년 정해진찬도(유물번호: 덕6184)(National Museum of Korea, 2010)에 그려진 장생보연지무와 명칭만 다 를 뿐 춤사위가 동일하므로 같은 정재임을 알 수 있다(Fig. 9). 『무신진찬의궤』권3 공령조에 “각무 정재여령은 화관, 황초단 삼, 리남색상 표홍초상, 홍단금루수대, 오색한삼, 초록혜를 착용
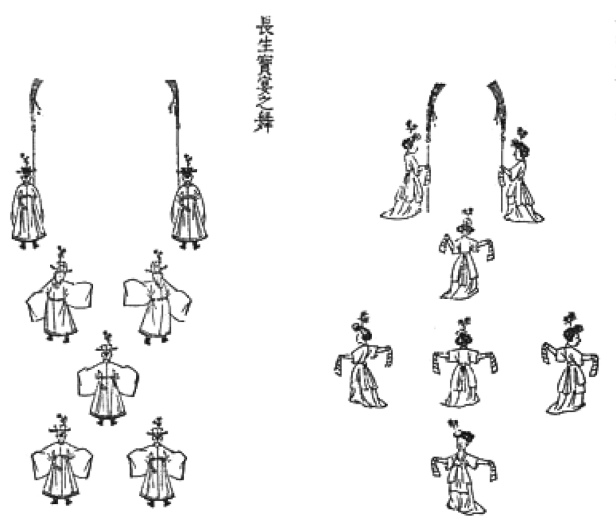

Fig. 1. Jangsaengboyeonjimu, 『Sunjo Gichuk Jinchan Uigwe』 (1829), Gyu14370. http://e-kyujanggak.snu.ac.kr

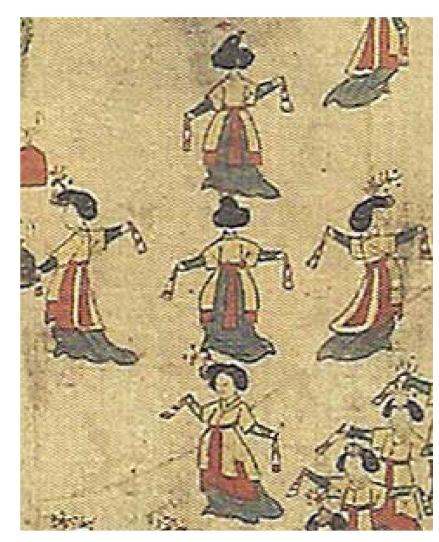

Fig. 2. Jangsaengboyeonjimu, Royal banquet in the year of Gichuk, 1829, National Museum of Korea (2010), p. 53.

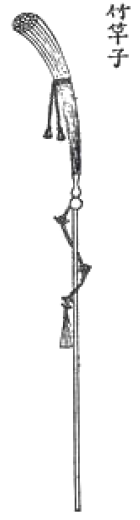

Fig. 3. Jukganja[bamboo staff] 『Sunjo Gichuk Jinchan Uigwe』 (1829), Gyul4370, from http://ekyujanggak.snu.ac.kr 


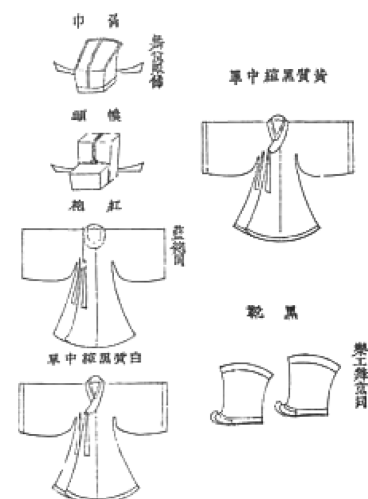

Fig. 4. Dresses worn by boy dancers, Jinchan Uigwe』 (1829), Gyu14370. http://e-kyujanggak.snu.ac.kr

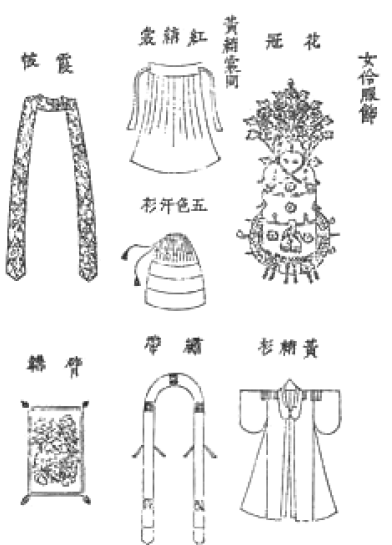

Fig. 5. Dresses worn by female dancers, ${ }^{『}$ Sunjo Gichuk Jinchan Uigwe』 (1829), Gyu14370.

http://e-kyujanggak.snu.ac.kr

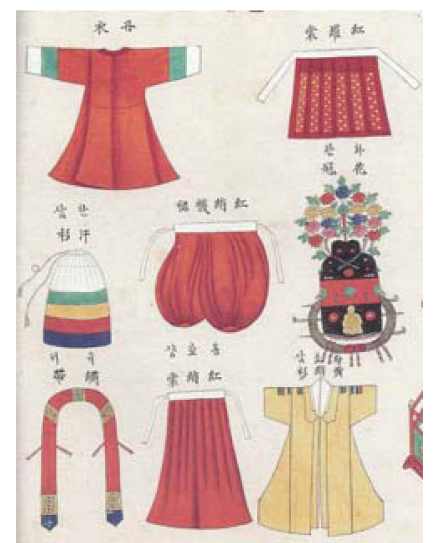

Fig. 6. Dresses worn by female dancers, Illustrations of record of King Jeongjo's visit to his father's tomb, 19C, National Museum of Korea (2012), p. 159.

한다.”고 기록되어 있다. 『무신진찬의계』 권수 복식도에 그 려진 일반 여령의 복식은 Fig. 10 의 왼쪽 그림에 보이는 바와 같다. 『기축진찬의궤」에 보이는 여령 복식 Fig. 5 와 비교해 볼 때, 화관의 크기가 많이 축소되어 족두리 형상으로 변화했 고, 황초삼의 배래 곡선이 완만해 졌으며, 홍초상의 형태가 일 반치마와 같이 폭이 더 넓어지면서 옆선의 곡선이 사라졌다. 수 대의 문양 배치도 조금 바뀌었다.

Fig. 8과 Fig. 9에 보이는 바와 같이 1848년과 1887년 장생 보연지무 여령은 머리에 족두리 모양의 화관을 쓰고, 기본복으 로 수구에 흰색 끝동이 달린 녹색 저고리와 남색 치마를 입었 다. 남 치마 위에 홍 치마를 덧입었고, 표의로는 반소매의 황

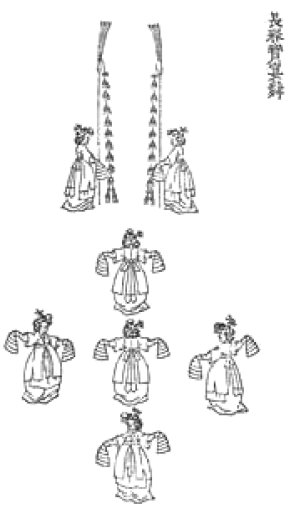

Fig. 7. Jangchunboyeonjimu,

${ }^{\circledR}$ Heonjong Musin Jinchan Uigwe』 (1848), Gyu14372. http://e-kyujanggak.snu.ac.kr

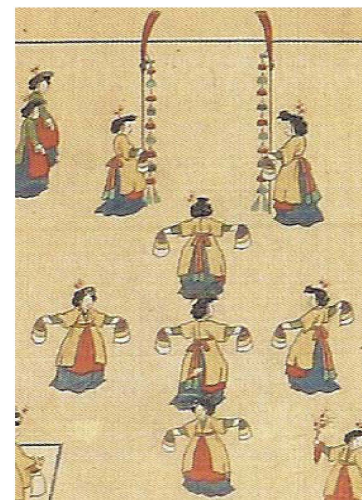

Fig. 8. Jangsaengboyeonjimu, Royal banquet in the year of Musin, 1848, National Museum of Korea (2010), p. 101.
색 삼을 입고 있다. 허리에는 홍색 대를 매었는데 대의 끝 부 분 색은 초록이다. 손에는 오색한삼을 들었는데 오색의 구성과 배치는 그림마다 조금씩 달랐다. 이러한 복식 구성은 연세대학 교 박물관 소장 광무 5년(1901) 신축진연도(Nam, 1995)에 채 색으로 그려진 장생보연지무 여령 복식과 거의 차이가 없다.

Fig. 11은 광무 6년(1902) 『임인진연의궤 에 전하는 장생보 연지무로, 고종 29년(1892) 『임진진찬의궤」와 동일하게 그려 져 있다. 외연에는 무동이, 내연에는 여령이 추고 있다. 고종 29년(1892) 『임진진찬의궤』 이후의 의궤에서 장생보연지무 무동복식에 관한 별도의 기록이 존재하지 않음을 볼 때, 1892 년 이후 장생보연지무의 무동은 모두 일반 무동의 복식을 입었

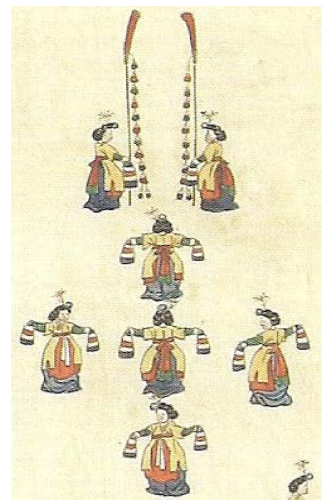

Fig. 9. Jangsaengboyeonjimu, Royal banquet in the year of Jeonghae, 1887, National Museum of Korea (2010), p. 145.

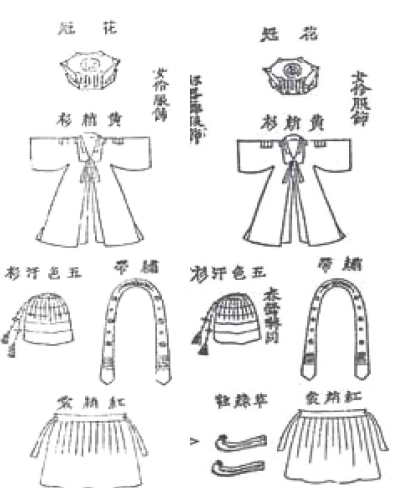

Fig. 10. Dresses worn by female dancers: left ${ }^{『}$ Heonjong Musin Jinchan Uigwe』 (1848), Gyu14372; right ${ }^{\mathbb{G}}$ Gojong Jeonghae Jinchan Uigwe』(1887), Gyu14405.

http://e-kyujanggak.snu.ac.kr 

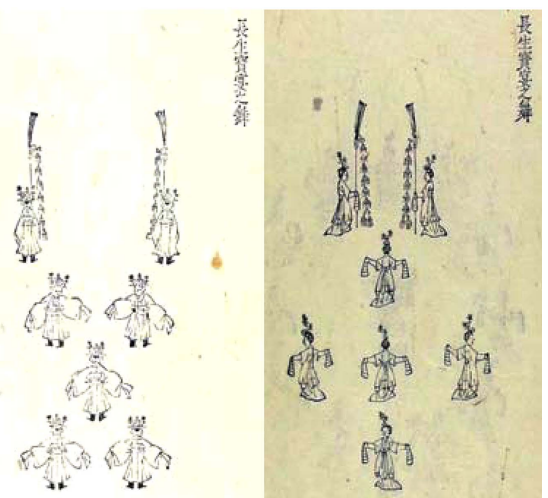

Fig. 11. Jangsaengboyeonjimu, ${ }^{\mathbb{G}}$ Gojong Imin Jinyeon Uigwe』(1902), Gyu14494. http://e-kyujanggak.snu.ac.kr

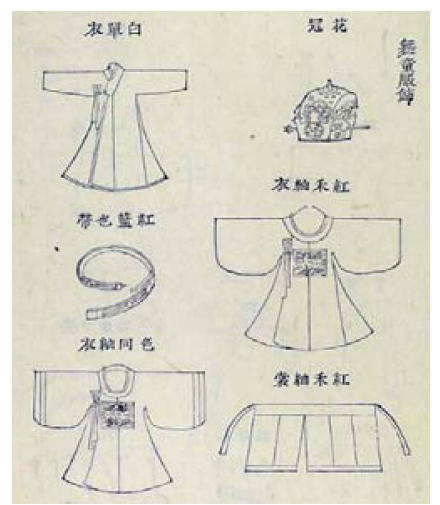

Fig. 12. Dresses worn by boy dancers, "Gojong Fig. 13. Dresses worn by female dancers, Imin Jinyeon Uigwe』(1902), Gyu14494. http://e-kyujanggak.snu.ac.kr

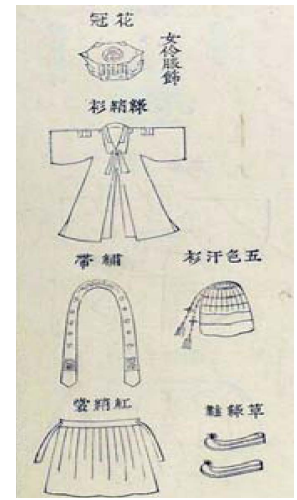

${ }^{\mathbb{G}}$ Gojong Imin Jinyeon Uigwe』(1902), Gyu14494. http://e-kyujanggak.snu.ac.kr
음을 알 수 있다. 이들의 복식 형태에 대해서는 복식도에 그려 진 일반 무동 복식 Fig. 12를 참고 할 수 있다. 이전 시기의 장생보연지무 무동 복식과 비교해 볼 때, 구성 품목 및 형태의 변화가 나타난다. 순조 29년(1829)의 제도와 비교해 보면, 각건 이 화관으로 바뀌었고, 홍포의 이름이 홍화주의(紅禾紬衣)로 바 뀌면서 가슴에 흥배를 부착하고 있다. 홍색의 하상(紅禾紬裳)이 새로 생겨났으며, 백단의(白單衣)의 소매통이 좁아지고 선이 사 라졌다. 하상의 경우 홍화주의 속에 입어서 가려졌기 때문인지 정재도 Fig. 11에서는 확인되지 않는다.

고종 29년(1892) 및 광무 6년(1902)의 일반 여령 복식의 구 성 품목 및 형태(Fig. 13)는 헌종 14년(1848)의 제도가 거의 그대로 이어지고 있다. 다만 한 가지 변화라고 한다면, 복색에 있어서 일반 여령의 단삼색이 고종 29년(1892)까지는 황색(共 單衫)이던 것이 광무 5년(1901) 이후에는 녹색(綠單衫)으로 바
뀌었다는 점이다. 그러나 광무 5년(1901) 신축진연도에 보이는 여령의 단삼이 여전히 모두 황색임을 볼 때 바뀐 제도의 실효 성 여부가 확실치는 않다. 장생보연지무 복식을 시기별로 정리 하면 Table 1과 같다.

\section{2. 연백복지무(演百福之舞)}

Fig. 14는 순조 29년(1829) 『기축진찬의궤』에 전하는 연백 복지무로 2 인의 무동이 죽간자를 들었고, 그 아래에는 5 인의 무동이 춤을 추고 있다. 순조 29 년의 『진찬의궤』권3 부편 공령조에 “연백복지무 무동 중 원무(元舞)는 각건(角巾), 홍포(紅 袍), 백질흑선중단의(白質黑線中單衣), 남야대(藍也帶), 흑화(黑 靴)를 신고, 선모(仙母) 및 죽간자(竹等子) 무동은 복두(幞頭), 남 포(藍袍), 백질흑선중단의, 홍야대(紅也帶), 흑화를 신는다.”고 기 록되어 있다. 역할에 따라 무동 복식이 달랐음을 알 수 있다.

Table 1. Dancing garments of the Jangsaengboyeonjimu(長生寶宴之舞)

\begin{tabular}{|c|c|c|c|c|c|c|c|c|}
\hline Year & Wearer & Tops & Bottoms & Waist-belt & Head-dresses & Shoes & Others & Resources \\
\hline \multirow[t]{2}{*}{1829} & $\begin{array}{l}\text { Boy dancers } \\
\text { [舞童] }\end{array}$ & $\begin{array}{c}\text { Red robe[紅袍], } \\
\text { Black-trimmed } \\
\text { white under garment } \\
\text { [白質黑線中單衣] }\end{array}$ & & $\begin{array}{l}\text { Blue belt } \\
\text { [藍也帶] }\end{array}$ & $\begin{array}{l}\text { Gakgeon } \\
\text { (角巾) }\end{array}$ & $\begin{array}{c}\text { Black boots } \\
\text { [黑靴] }\end{array}$ & & \multirow[t]{2}{*}{$\begin{array}{c}\text { Jinchan } \\
\text { Uigwe(1829) }\end{array}$} \\
\hline & $\begin{array}{c}\text { Female dancers } \\
\text { [女伶] }\end{array}$ & $\begin{array}{l}\text { Yellow robe } \\
\text { [黃綃單衫] }\end{array}$ & $\begin{array}{l}\text { Red skirt with a blue } \\
\text { under skirt } \\
\text { [裏藍色裳表紅綃裳] }\end{array}$ & $\begin{array}{c}\text { Embroidered } \\
\text { red belt } \\
\text { [紅緞金鏤繡帶] }\end{array}$ & $\begin{array}{c}\text { Flower } \\
\text { headdress } \\
\text { [花冠] }\end{array}$ & $\begin{array}{c}\text { Greenshoes } \\
\text { [草綠鞋] }\end{array}$ & $\begin{array}{c}\text { Five-colored } \\
\text { Hansam } \\
\text { [五彩汗衫] }\end{array}$ & \\
\hline 1848 & $\begin{array}{c}\text { Female dancers } \\
\text { [女伶] }\end{array}$ & $\begin{array}{l}\text { Yellow robe } \\
\text { [黄綃單衫] }\end{array}$ & $\begin{array}{c}\text { Red skirt with a blue } \\
\text { under skirt } \\
\text { [裏藍色裳表紅綃裳] }\end{array}$ & $\begin{array}{l}\text { Embroidered red } \\
\text { belt } \\
\text { [紅緞金鏤繡帶] }\end{array}$ & $\begin{array}{c}\text { Flower } \\
\text { headdress } \\
\text { [花冠] }\end{array}$ & $\begin{array}{c}\text { Greenshoes } \\
\text { [草綠鞋] }\end{array}$ & $\begin{array}{c}\text { Five-colored } \\
\text { Hansam } \\
\text { [五色汗衫] }\end{array}$ & $\begin{array}{c}\text { Jinchan } \\
\text { Uigwe(1848) }\end{array}$ \\
\hline 1901 & $\begin{array}{c}\text { Female dancers } \\
\text { [女伶] }\end{array}$ & $\begin{array}{c}\text { Yellow robe } \\
\text { [黃綃衫] }\end{array}$ & $\begin{array}{l}\text { Red skirt } \\
\text { [紅綃裳] }\end{array}$ & $\begin{array}{c}\text { Embroidered red } \\
\text { belt } \\
\text { [紅繡帶] }\end{array}$ & $\begin{array}{c}\text { Flower } \\
\text { headdress } \\
\text { [花冠] }\end{array}$ & & $\begin{array}{c}\text { Five-colored } \\
\text { Hansam } \\
\text { [五色汗衫] }\end{array}$ & $\begin{array}{c}\text { Sinchuk } \\
\text { Jinyeondo(1901) }\end{array}$ \\
\hline $\begin{array}{l}1892 \\
1902\end{array}$ & $\begin{array}{c}\text { Boy dancers } \\
\text { [舞童] }\end{array}$ & $\begin{array}{c}\text { Red jacket } \\
\text { [紅禾紬衣], } \\
\text { White under garment } \\
\text { [白單衣] }\end{array}$ & $\begin{array}{l}\text { Red skirt } \\
\text { [紅禾紬裳] }\end{array}$ & $\begin{array}{l}\text { Red or blue belt } \\
\text { [紅藍也帶] }\end{array}$ & $\begin{array}{c}\text { Flower } \\
\text { headdress } \\
\text { [花冠] }\end{array}$ & & $\begin{array}{l}\text { Insignia } \\
\text { [胸背] }\end{array}$ & $\begin{array}{c}\text { Jinchan } \\
\text { Uigwe(1892) } \\
\text { Jinyeon } \\
\text { Uigwe(1902) }\end{array}$ \\
\hline
\end{tabular}




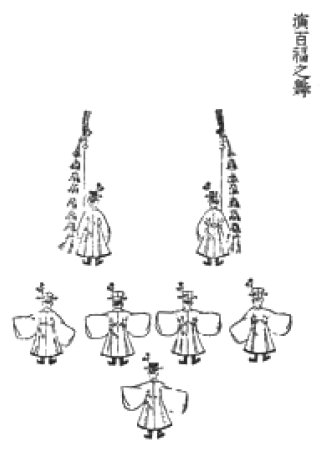

Fig. 14. Yeonbaekbokjimu, "Sunjo Gichuk Jinchan Uigwe』 (1829), Gyu14370. http://e-kyujanggak.snu.ac.kr

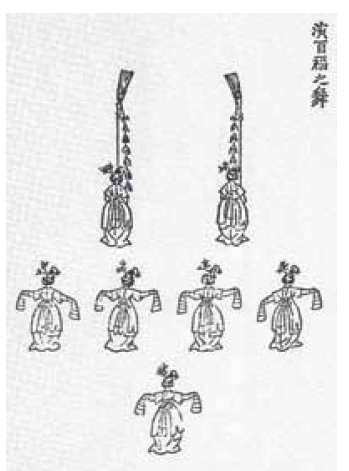

Fig. 15. Yeonbaekbokjimu, ${ }^{\circledR}$ Gojong Jeonghae Jinchan Uigwe』 (1887), Gyu14405. http://e-kyujanggak.snu.ac.kr

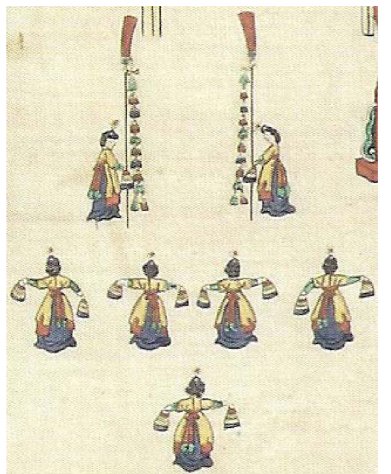

Fig. 16. Yeonbaekbokjimu, Royal banquet in the year of Jeonghae, 1887, National Museum of Korea (2010), p. 150.

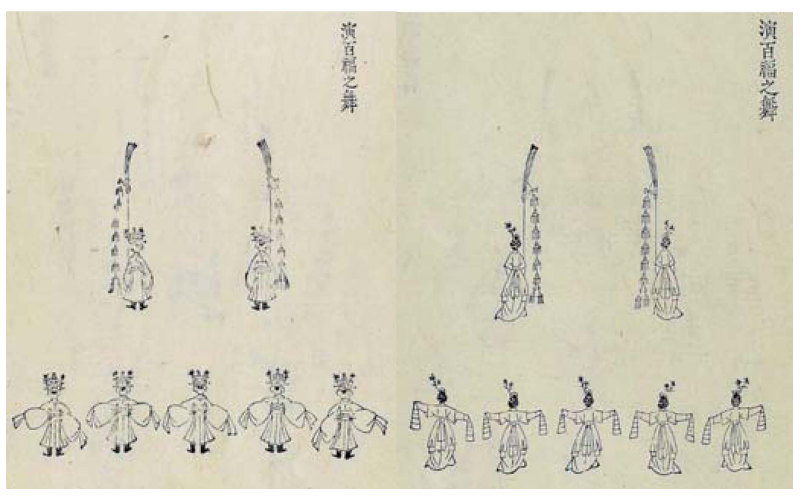

Fig. 17. Yeonbaekbokjimu, ${ }^{『}$ Gojong Imin Jinyeon Uigwe』(1902), Gyu14494. http://e-kyujanggak.snu.ac.kr

원무 무동의 복식은 순조 29년(1829) 장생보연지무 무동 복식 과 동일하다. 선모 및 죽간자 무동이 착용한 복두의 형태는 Fig. 4에 그려진 바와 같이 앞이 낮고 뒤가 높은 식으로 층이
진 형태이며 양 각이 달려 있다.

Fig. 15는 고종 24년(1887) 『정해진찬의궤』에 전하는 연백 복지무이다. 동일한 춤사위가 국립중앙박물관 소장 1887 년 정 해진찬도(유물번호: 덕6184)(National Museum of Korea, 2010)에 그려져 있다(Fig. 16). 고종 24년(1887)의 장생보연지 무와 마찬가지로 일반 여령의 복식을 입은 것으로 판단된다 (Fig. 10). Fig. 17은 광무 6년(1902) 『임인진연의궤』에 전하는 연백복지무로 고종 29년(1892)『임진진찬의궤』와 동일하게 그 려져 있다. 외연에서는 무동이, 내연에서는 여령이 연행했는데, 앞에는 2 인이 죽간자를 들었고 그 아래에는 5 인이 나란히 춤 을 추고 있다. 1829 년과 1887 년에 원무가 앞으로 나선 것으로 표현되었던 바와는 다소 차이가 난다. 고종 29년(1892)년, 광무 6년(1902)의 연백복지무 무동과 여령은 장생보연지무와 마찬가 지로 일반 무동 및 일반 여령의 복식을 입었던 것으로 판단된 다(Fig. 12 and Fig. 13). 연백복지무 복식을 시기별로 정리하 면 Table 2와 같다.

Table 2. Dancing garments of the Yeonbaekbokjimu(演百福之舞)

\begin{tabular}{|c|c|c|c|c|c|c|c|c|}
\hline Year & Wearer & Tops & Bottoms & Waist-belt & Head-dresses & Shoes & Others & Resources \\
\hline \multirow{2}{*}{1829} & $\begin{array}{l}\text { Leading boy } \\
\text { dancer } \\
\text { [元舞舞童] }\end{array}$ & $\begin{array}{c}\text { Red robe[紅袍], } \\
\text { Black-trimmed } \\
\text { white under garment } \\
\text { [白質黑線中單衣] }\end{array}$ & & $\begin{array}{l}\text { Blue belt } \\
\text { [藍也帶] }\end{array}$ & $\begin{array}{l}\text { Gakgeon } \\
\text { (角巾) }\end{array}$ & $\begin{array}{c}\text { Black boots } \\
\text { [黑靴] }\end{array}$ & & \multirow{2}{*}{$\begin{array}{c}\text { Jinchan } \\
\text { Uigwe(1829) }\end{array}$} \\
\hline & $\begin{array}{l}\text { Seonmo (仙母) } \\
\text { and boy dancer } \\
\text { with a jukganja }\end{array}$ & $\begin{array}{c}\text { Blue robe[藍袍], } \\
\text { Black-trimmed } \\
\text { white under garment } \\
\text { [白質黑線中單衣] }\end{array}$ & & $\begin{array}{l}\text { Red belt } \\
\text { [紅也帶] }\end{array}$ & $\begin{array}{l}\text { Bokdu } \\
\text { (㡤頭) }\end{array}$ & $\begin{array}{c}\text { Black boots } \\
\text { [黑靴] }\end{array}$ & & \\
\hline 1887 & $\begin{array}{l}\text { Female } \\
\text { dancers } \\
\text { [女伶] }\end{array}$ & $\begin{array}{l}\text { Yellow robe } \\
\text { [黃綃單衫] }\end{array}$ & $\begin{array}{c}\text { Red skirt with a blue } \\
\text { under skirt } \\
\text { [裏藍色裳表紅綃裳] }\end{array}$ & $\begin{array}{c}\text { Embroidered red } \\
\text { belt } \\
\text { [紅紼金鏤繡帶 }]\end{array}$ & $\begin{array}{l}\text { Flower } \\
\text { headdress } \\
\text { [花冠] }\end{array}$ & $\begin{array}{c}\text { Greenshoes } \\
\text { [草綠鞋] }\end{array}$ & $\begin{array}{c}\text { Five-colored } \\
\text { Hansam } \\
\text { [五色汗衫] }\end{array}$ & $\begin{array}{c}\text { Jinchan } \\
\text { Uigwe(1887) }\end{array}$ \\
\hline \multirow{2}{*}{$\begin{array}{l}1892 \\
1902\end{array}$} & $\begin{array}{c}\text { Boy dancers } \\
\text { [舞童] }\end{array}$ & $\begin{array}{c}\text { Red jacket[紅禾紬衣], } \\
\text { White under garment } \\
\text { [白單衣] }\end{array}$ & $\begin{array}{l}\text { Red skirt } \\
\text { [紅禾紬裳] }\end{array}$ & $\begin{array}{l}\text { Red or blue belt } \\
\text { [紅藍也帶] }\end{array}$ & $\begin{array}{c}\text { Flower } \\
\text { headdress } \\
\text { [花冠] }\end{array}$ & & $\begin{array}{l}\text { Insignia } \\
\text { [胸背] }\end{array}$ & $\begin{array}{c}\text { Jinchan } \\
\text { Uigwe(1892) }\end{array}$ \\
\hline & $\begin{array}{l}\text { Female } \\
\text { dancers } \\
\text { [女伶] }\end{array}$ & $\begin{array}{l}\text { Yellow robe [黃綃單衫] } \\
\text { (or possible to wear green } \\
\text { robe [綠綃單衫] in 1902) }\end{array}$ & $\begin{array}{l}\text { Red skirt with a blue } \\
\text { under skirt } \\
\text { [裏藍色裳表紅綃裳] }\end{array}$ & $\begin{array}{c}\text { Embroidered red } \\
\text { belt } \\
\text { [紅緞金鏤繡帶 }]\end{array}$ & $\begin{array}{c}\text { Flower } \\
\text { headdress } \\
\text { [花冠] }\end{array}$ & $\begin{array}{c}\text { Greenshoes } \\
\text { [草綠鞋] }\end{array}$ & $\begin{array}{c}\text { Five-colored } \\
\text { Hansam } \\
\text { [五色汗衫] }\end{array}$ & $\begin{array}{c}\text { Jinyeon } \\
\text { Uigwe(1902) }\end{array}$ \\
\hline
\end{tabular}



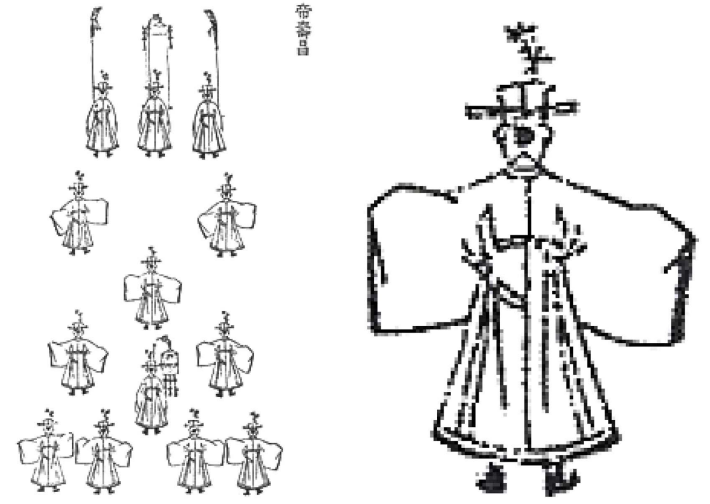

Fig. 18. Jesuchang, "Sunjo Gichuk Jinchan Uigwe』 (1829), Gyu14370. http://e-kyujanggak.snu.ac.kr
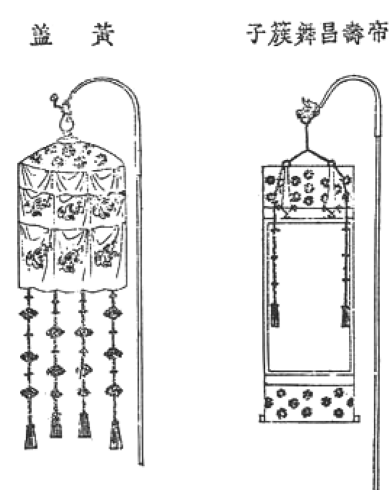

Fig. 19. Jokja[hanging scroll] and Hwanggae[yellow cover], ${ }^{\text {SSunjo Gichuk }}$ Jinchan Uigwe』(1829), Gyu14370. http://e-kyujanggak.snu.ac.kr

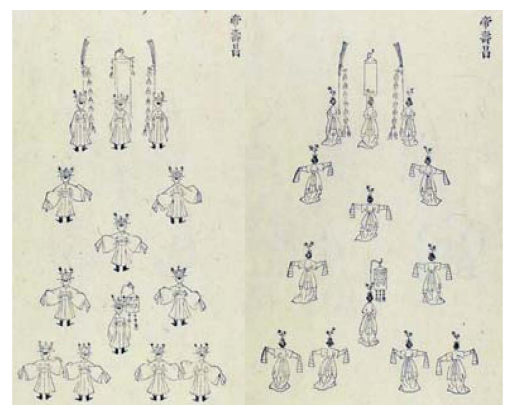

Fig. 20. Jesuchang, ${ }^{『}$ Gojong Imin Jinyeon Uigwe』 (1902), Gyu14494. http://e-kyujanggak.snu.ac.kr

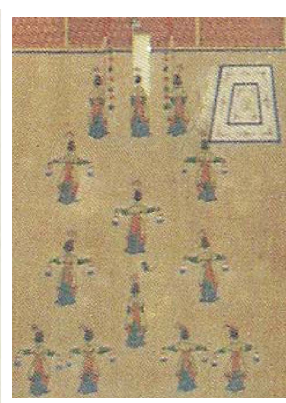

Fig. 21. Jesuchang, shown in Jinyeondo screen, 1901,

Nam(1995), p. 190.

\section{3. 제수창(帝壽昌)}

Fig. 18은 순조 29년(1829) 『기축진찬의궤」에 전하는 제수 창으로 앞의 가운데 무동 1 인은 족자(簇子)를 들었고, 앞의 양

옆 무동 2 인은 죽간자를 들었으며, 아래에는 10 인의 무동이 춤 을 추고 있다. 그 가운데 1 인은 황개(黃蓋)를 들고 있다. 제수 창에 이용된 족자와 황개의 형상은 Fig. 19와 같다. 『기축진 찬의궤』 권3 공령조에는 제수창 무동 복식에 관한 별도의 기 록이 나타나지 않는다. 그러나 Fig. 18에 보이는 바와 같이 제 수창 정재도에서 무동들이 각건을 쓴 모습으로 그려진 것을 볼 때, 순조 29년(1829) 외연에서 제수창 무동들이 장생보연지무 무 동과 동일한 품목들, 즉 각건, 홍포, 백질흑선중단의, 남야대, 흑 화를 착용했을 가능성이 있다.

Fig. 20은 광무 6년(1902) 『임인진연의계」에 전하는 제수창 으로 고종 29년(1892) 『임진진찬의궤」와 동일하게 그려져 있 다. 외연에서는 무동이, 내연에서는 여령이 연행하고 있다. 고 종 29년(1892)년, 광무 6년(1902)의 제수창 무동은 장생보연지 무, 연백복지무와 마찬가지로 당시의 일반 무동 복식을 따랐던 것으로 보인다(Fig. 12).

Fig. 21은 광무 5년(1901) 신축진연도에 그려진 제수창으로

Table 3. Dancing garments of the Jesuchang(帝壽昌)

\begin{tabular}{|c|c|c|c|c|c|c|c|c|}
\hline Year & Wearer & Tops & Bottoms & Waist-belt & Head-dresses & Shoes & Others & Resources \\
\hline 1829 & $\begin{array}{c}\text { Boy dancers } \\
\text { [舞童] }\end{array}$ & $\begin{array}{c}\text { Red robe[紅袍], } \\
\text { Black-trimmed } \\
\text { white under garment } \\
\text { [白質黑線中單衣] }\end{array}$ & & $\begin{array}{l}\text { Blue belt } \\
\text { [藍也帶] }\end{array}$ & $\begin{array}{c}\text { Gakgeon } \\
\text { (角巾) }\end{array}$ & $\begin{array}{c}\text { Black boots } \\
\text { [黑靴] }\end{array}$ & & $\begin{array}{c}\text { Jinchan } \\
\text { Uigwe(1829) }\end{array}$ \\
\hline $\begin{array}{l}1892 \\
1902\end{array}$ & $\begin{array}{c}\text { Female dancers } \\
\text { [女伶] }\end{array}$ & $\begin{array}{c}\text { Red jacket } \\
\text { [紅禾紬衣], } \\
\text { White under garment } \\
\text { [白單衣] } \\
\text { Yellow robe } \\
\text { [黃綃單衫] } \\
\text { (or possible to wear } \\
\text { green robe } \\
\text { [綠綃單衫] in 1902) }\end{array}$ & $\begin{array}{c}\text { Red skirt } \\
\text { [紅禾紬裳] } \\
\text { Red skirt with a blue } \\
\text { under skirt } \\
\text { [裏藍色裳表紅綃裳] }\end{array}$ & $\begin{array}{l}\text { Red or blue belt } \\
\text { [紅藍也帶] }\end{array}$ & $\begin{array}{c}\text { Flower } \\
\text { headdress } \\
\text { [花冠] }\end{array}$ & $\begin{array}{c}\text { Greenshoes } \\
\text { [草綠鞋] }\end{array}$ & $\begin{array}{l}\text { Five-colored } \\
\text { Hansam } \\
\text { [五色汗衫] }\end{array}$ & $\begin{array}{c}\text { Jinchan } \\
\text { Uigwe(1892) } \\
\text { Jinyeon } \\
\text { Uigwe(1902) }\end{array}$ \\
\hline 1901 & $\begin{array}{c}\text { Female dancers } \\
\text { [女伶] }\end{array}$ & $\begin{array}{c}\text { Yellow robe } \\
\text { [黃綃衫] }\end{array}$ & $\begin{array}{l}\text { Red skirt } \\
\text { [紅綃裳] }\end{array}$ & $\begin{array}{c}\text { Embroidered red } \\
\text { belt[紅繣帶] }\end{array}$ & $\begin{array}{c}\text { Flower } \\
\text { headdress } \\
\text { [花冠] }\end{array}$ & & $\begin{array}{l}\text { Five-colored } \\
\text { Hansam } \\
\text { [五色汗衫] }\end{array}$ & $\begin{array}{c}\text { Sinchuk } \\
\text { Jinyeondo(1901) }\end{array}$ \\
\hline
\end{tabular}




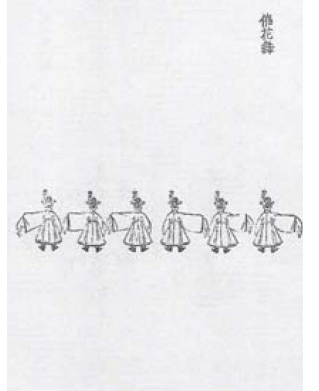

Fig. 22. Choehwamu,

『Sunjo Muja Jinjak Uigwe』 (1828), Gyu14364

http://e-kyujanggak.snu.ac.kr

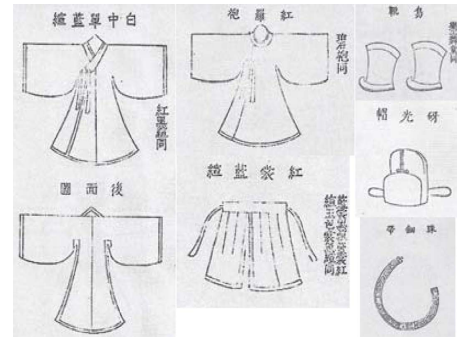

Fig. 23. Dresses worn by boy dancers, 『Sunjo Muja Jinjak Uigwe』(1828), Gyu14364.

http://e-kyujanggak.snu.ac.kr

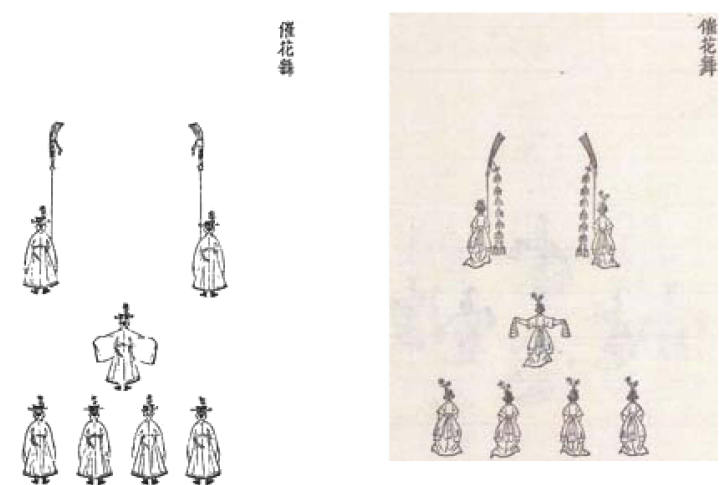

Fig. 24. Choehwamu, "Sunjo Gichuk Jinchan Uigwe』 (1829), Gyul4370.

http://e-kyujanggak.snu.ac.kr

Fig. 25. Choehwamu, ${ }^{『}$ Gojong Imjin Jinchan Uigwe』(1892), Gyu 14428.

http://e-kyujanggak.snu.ac.kr

앞의 가운데 여령 1 인은 족자를 들었고, 앞의 양 옆 여령 2 인 은 죽간자를 들었으며, 아래에는 10 인의 여령이 춤을 추고 있 다. 여령의 복식은 화관, 황초삼, 홍초상, 수대, 오색한삼으로 일반 여령의 복식과 동일한 것으로 판단된다. 광무 6년(1902) 『임인진연의궤』와 고종 29년(1892)『임진진찬의궤』에 전하는

제수창 여령도 장생보연지무, 연백복지무와 마찬가지로 당시의 일반 여령 복식을 따랐던 것으로 판단된다(Fig. 13). 제수창 복 식을 시기별로 정리하면 Table 3과 같다.

\section{4. 최화무(催花舞)}

Fig. 22는 순조 28년(1828) 『무자진작의궤』에 전하는 최화무 로 무동 6 명이 나란히 춤을 추고 있다. 『무자진작의궤』 권부 편 공령조에 “춘광호, 첩승, 최화무 무동은 아광모, 홍라포, 백질 흑선중단의, 남질흑선상, 주전대, 흑화를 신는다."고 기록되어 있 다. 1828년 최화무 무동이 착용한 복식의 형태는 Fig. 23에 그 려진 바와 같다. 아광모는 모정이 둥글고 높은 사모와 유사한 형 상인데 앞 중앙에 실꼬임인 듯한 장식선을 댄 것이 특징이다. 홍 라포는 흉배가 없는 대수 단령포이다. 백질흑선중단의는 '백중 단남선'의 도식 우측에 '홍흑선동(紅黑縇同)'이라 기록되어 있 어 색만 다르고 제도가 같았음을 알 수 있는데, 대수의 직령 깃 의 포이며 깃, 수구, 도련, 옆선에 선을 둘렀다. 남질흑선상 역 시 '홍상남선'의 도식 우측의 '남상흑선 남상홍선 옥색상흑선 동(藍裳黑縇藍裳紅縇玉色裳黑縇同)'기록을 기준으로 형상을 이 해할 수 있는데, 치마의 앞과 뒤가 분리된 의례용 상 형태로서 앞폭과 뒤폭의 너비가 다르며 밑단과 옆트임에 선을 둘렀다. 주 전대는 야자대(야대)와 달리 늘어진 부분이 그려져 있지 않다. 흑화는 전악, 악공, 무동이 함께 착용한 것으로 기록되어 있는 오화(烏靴)를 지칭하는 것으로 판단된다. 신코가 약간 올라와 있 고 바닥이 얇으며 특별한 장식이 없는 목화(木靴)의 형태이다.

Fig. 24는 순조 29년(1829) 『기축진찬의궤』에 전하는 최화 무로 앞에는 2 인의 무동이 죽간자를 들고 있고 아래에는 5 인 의 무동이 춤을 추고 있다. 순조 28년(1828) 최화무의 춤사위 와 같지 않다. 또한 순조 28년(1828) 최화무에는 보이지 않았 던 죽간자가 그려져 있는 것으로 보아 당악 정재의 형식을 더 욱 갖춘 것으로 보인다. 『기축진찬의궤』 권3 부편 공령조에 서 최화무 무동의 복식은 장생보연지무 무동의 복식과 동일하 게 각건, 홍포, 백질흑선중단의, 남야대, 흑화로 기록되어 있다. 1828 년의 최화무 무동 복식의 종류와 비교해 볼 때, 관모와 대 에 있어서 차이를 보이고 있다. 1828 년에는 아광모와 주전대를 사

Table 4. Dancing garments of the Choehwamu(催花舞)

\begin{tabular}{|c|c|c|c|c|c|c|c|c|}
\hline Year & Wearer & Tops & Bottoms & Waist-belt & Head-dresses & Shoes & Others & Resources \\
\hline 1828 & $\begin{array}{c}\text { Boy } \\
\text { dancers } \\
\text { [舞童] }\end{array}$ & $\begin{array}{c}\text { Red robe[紅羅袍], } \\
\text { Black-trimmed } \\
\text { white under garment } \\
\text { [白質黑線中單衣] }\end{array}$ & $\begin{array}{c}\text { Black-trimmed blue } \\
\text { skirt[藍質黑線裳] }\end{array}$ & $\begin{array}{l}\text { Jujeondae } \\
\text { (珠鈿帶) }\end{array}$ & $\begin{array}{l}\text { Agwangmo } \\
\text { (砑光帽) }\end{array}$ & $\begin{array}{c}\text { Black boots } \\
\text { [黑靴] }\end{array}$ & & $\begin{array}{c}\text { Jinjak Uigwe } \\
(1828)\end{array}$ \\
\hline 1829 & $\begin{array}{c}\text { Boy } \\
\text { dancers } \\
\text { [舞童] }\end{array}$ & $\begin{array}{c}\text { Red robe[紅袍], } \\
\text { Black-trimmed } \\
\text { white under garment } \\
\text { [白質黑線中單衣] }\end{array}$ & & $\begin{array}{l}\text { Blue belt } \\
\text { [藍也帶] }\end{array}$ & $\begin{array}{l}\text { Gakgeon } \\
\text { (角巾) }\end{array}$ & $\begin{array}{c}\text { Black boots } \\
\text { [黑靴] }\end{array}$ & & $\begin{array}{c}\text { Jinchan } \\
\text { Uigwe(1829) }\end{array}$ \\
\hline $\begin{array}{l}1892 \\
1902\end{array}$ & $\begin{array}{l}\text { Female } \\
\text { dancers } \\
\text { [女伶] }\end{array}$ & $\begin{array}{c}\text { Yellow robe[黃綃單衫] } \\
\text { (or possible to wear green } \\
\text { robe[綠綃單衫] in 1902) }\end{array}$ & $\begin{array}{c}\text { Red skirt with a blue } \\
\text { under skirt } \\
\text { [裏藍色裳表紅 綃裳] }\end{array}$ & $\begin{array}{c}\text { Embroidered red } \\
\text { belt } \\
\text { [紅緞金鏤繡帶] }\end{array}$ & $\begin{array}{c}\text { Flower } \\
\text { headdress } \\
\text { [花冠] }\end{array}$ & $\begin{array}{c}\text { Green shoes } \\
\text { [草綠鞋] }\end{array}$ & $\begin{array}{c}\text { Five-colored } \\
\text { Hansam } \\
\text { [五色汗衫] }\end{array}$ & $\begin{array}{c}\text { Jinchan } \\
\text { Uigwe(1892) } \\
\text { Jinyeon } \\
\text { Uigwe(1902) }\end{array}$ \\
\hline
\end{tabular}


Table 5. Boy dancer's garments of the Jangsengboyeonjimu, Yeonbaekbokjimu, Jesuchang, and Choehwamu

\begin{tabular}{|c|c|c|c|c|c|c|c|c|}
\hline Year & Court dances & Tops & Bottoms & Waist-belt & Head-dresses & Shoes & Others & Resources \\
\hline 1828 & Choehwamu & $\begin{array}{c}\text { Red robe[紅羅袍], } \\
\text { Black-trimmed } \\
\text { white under garment } \\
\text { [白質黑線中單衣] }\end{array}$ & $\begin{array}{l}\text { Black-trimmed } \\
\text { blue skirt } \\
\text { [藍質黑線裳] }\end{array}$ & $\begin{array}{l}\text { Jujeondae } \\
\text { (珠鈿帶) }\end{array}$ & $\begin{array}{l}\text { Agwangmo } \\
\text { (砑光帽) }\end{array}$ & $\begin{array}{l}\text { Black } \\
\text { boots } \\
{[\text { 黑靴 }]}\end{array}$ & & $\begin{array}{l}\text { Muja Jinjak } \\
\text { Uigwe(1828) }\end{array}$ \\
\hline \multirow[t]{2}{*}{1829} & $\begin{array}{l}\text { Jangsengboyeonjimu, } \\
\text { Choehwamu, Jesuchang, } \\
\text { Leading boy dancer } \\
\text { [元舞舞童] of the } \\
\text { Yeonbaekbokjimu }\end{array}$ & $\begin{array}{c}\text { Red robe[紅袍], } \\
\text { Black-trimmed } \\
\text { white under garment } \\
\text { [白質黑線中單衣] }\end{array}$ & & $\begin{array}{l}\text { Blue belt } \\
\text { [藍也帶] }\end{array}$ & $\begin{array}{l}\text { Gakgeon } \\
\text { (角巾) }\end{array}$ & $\begin{array}{l}\text { Black } \\
\text { boots } \\
{[\text { 黑靴 }]}\end{array}$ & & \multirow{2}{*}{$\begin{array}{c}\text { Gichuk } \\
\text { Jinchan Uigwe } \\
(1829)\end{array}$} \\
\hline & $\begin{array}{c}\text { Seonmo [仙母] and boy } \\
\text { dancer with a jukganja of the } \\
\text { Yeonbaekbokjimu }\end{array}$ & $\begin{array}{c}\text { Blue robe[藍袍], } \\
\text { Black-trimmed } \\
\text { white under garment } \\
\text { [白質黑線中單衣] }\end{array}$ & & $\begin{array}{l}\text { Red belt } \\
\text { [紅也帶] }\end{array}$ & $\begin{array}{l}\text { Bokdu } \\
\text { (幞頭) }\end{array}$ & $\begin{array}{l}\text { Black } \\
\text { boots } \\
{[\text { 黑靴 }]}\end{array}$ & & \\
\hline 1892 & $\begin{array}{c}\text { Jangsengboyeonjimu, } \\
\text { Yeonbaekbokjimu, } \\
\text { Jesuchang }\end{array}$ & $\begin{array}{l}\text { Red jacket[紅禾紬衣], } \\
\text { White under garment } \\
\text { [白單衣] }\end{array}$ & $\begin{array}{l}\text { Red skirt } \\
\text { [紅禾紬裳] }\end{array}$ & $\begin{array}{l}\text { Red or blue } \\
\text { belt } \\
\text { [紅藍也帶] }\end{array}$ & $\begin{array}{c}\text { Flower } \\
\text { headdress } \\
\text { [花冠] }\end{array}$ & & $\begin{array}{c}\text { Insignia } \\
\text { [胸背] }\end{array}$ & $\begin{array}{c}\text { Imjin } \\
\text { Jinchan Uigwe } \\
(1892)\end{array}$ \\
\hline 1902 & $\begin{array}{c}\text { Jangsengboyeonjimu, } \\
\text { Yeonbaekbokjimu, } \\
\text { Jesuchang }\end{array}$ & $\begin{array}{c}\text { Red jacket[紅禾紬衣], } \\
\text { White under garment } \\
\text { [白單衣] }\end{array}$ & $\begin{array}{l}\text { Red skirt } \\
\text { [紅禾紬裳] }\end{array}$ & $\begin{array}{l}\text { Red or blue } \\
\text { belt } \\
\text { [紅藍也帶] }\end{array}$ & $\begin{array}{l}\text { Flower } \\
\text { headdress } \\
\text { [花冠] }\end{array}$ & & $\begin{array}{l}\text { Insignia } \\
\text { [胸背] }\end{array}$ & $\begin{array}{c}\text { Imin Jinyeon } \\
\text { Uigwe } \\
(1902)\end{array}$ \\
\hline
\end{tabular}

용했으나, 1829 년에는 각건과 남야대를 사용하고 있다(Table 4).

Fig. 25는 고종 29년(1892) 『임진진찬의계』내진연 정재도 에 전하는 최화무로 앞에 2 인의 여령이 죽간자를 들고 있고 가 운데 1 인, 뒤에 4 인의 여령이 춤을 추고 있다. 순조 29 년 (1829)의 최화무와 동일한 춤사위로 보인다. 1892년의 최화무 여령 역시 별도의 기록이 없음으로 보아 당시 일반 여령의 복 식을 따랐을 것으로 판단된다(Fig. 13). 광무 5년(1901)의 『신 축진찬의퀘」정재도에도『임진진찬의궤」와 동일한 구도로 여
령의 최화무가 그려져 있는데(Lee \& Son, 2010c), 이들 역시 일반 여령의 복식을 착용했던 것으로 판단된다. 『신축진찬의 궤」권3 공령조에 "각무 정재여령은 화관, 녹초단삼, 이남색상 표홍초상, 홍단금루수대, 오색한삼, 초록혜를 착용한다.”고 되어 있으며(Kim, 2005), 복식도에서는 여령의 녹초삼이 그려져 있 다(Lee \& Son, 2010c). 그러나 고려대학교 박물관 소장 광무 5년(1901)의 병풍에 그려진 진연도에서 여령들이 모두 황초삼 을 착용한 것으로 그려진 것으로 보아 앞서 언급한 바와 같이

Table 6. Female dancer's garments of the Jangsengboyeonjimu, Yeonbaekbokjimu, Jesuchang, and Choehwamu

\begin{tabular}{|c|c|c|c|c|c|c|c|c|}
\hline Year & Court dances & Tops & Bottoms & Waist-belt & Head-dresses & Shoes & Others & Resources \\
\hline 1829 & Jangsengboyeonjimu & $\begin{array}{l}\text { Yellow robe } \\
\text { [黃綃單衫] }\end{array}$ & $\begin{array}{c}\text { Red skirt with a blue } \\
\text { under skirt } \\
\text { [裏藍色裳表紅 綃裳] }\end{array}$ & $\begin{array}{c}\text { Embroidered red } \\
\text { belt[紅緞金鏤繡帶] }\end{array}$ & $\begin{array}{c}\text { Flower } \\
\text { headdress } \\
\text { [花冠] }\end{array}$ & $\begin{array}{c}\text { Greenshoes } \\
\text { [草綠鞋] }\end{array}$ & $\begin{array}{l}\text { Five-colored } \\
\text { Hansam } \\
\text { [五彩汗衫] }\end{array}$ & $\begin{array}{c}\text { Gichuk } \\
\text { Jinchan Uigwe } \\
(1829)\end{array}$ \\
\hline 1848 & Jangsengboyeonjimu & $\begin{array}{l}\text { Yellow robe } \\
\text { [黃綃單衫] }\end{array}$ & $\begin{array}{c}\text { Red skirt with a blue } \\
\text { under skirt } \\
\text { [裏藍色裳表紅 綃裳] }\end{array}$ & $\begin{array}{c}\text { Embroidered red } \\
\text { belt[紅緞金鏤繡帶] }\end{array}$ & $\begin{array}{c}\text { Flower } \\
\text { headdress } \\
\text { [花冠] }\end{array}$ & $\begin{array}{c}\text { Greenshoes } \\
\text { [草綠鞋] }\end{array}$ & $\begin{array}{l}\text { Five-colored } \\
\text { Hansam } \\
\text { [五色汗衫] }\end{array}$ & $\begin{array}{c}\text { Musin } \\
\text { Jinchan Uigwe } \\
(1848)\end{array}$ \\
\hline 1887 & Yeonbaekbokjimu & $\begin{array}{l}\text { Yellow robe } \\
\text { [黃綃單衫] }\end{array}$ & $\begin{array}{c}\text { Red skirt with a blue } \\
\text { under skirt } \\
\text { [裏藍色裳表紅 綃裳] }\end{array}$ & $\begin{array}{c}\text { Embroidered red } \\
\text { belt[紅緞金鏤繡帶] }\end{array}$ & $\begin{array}{l}\text { Flower } \\
\text { headdress } \\
\text { [花冠] }\end{array}$ & $\begin{array}{c}\text { Greenshoes } \\
\text { [草綠鞋] }\end{array}$ & $\begin{array}{l}\text { Five-colored } \\
\text { Hansam } \\
\text { [五色汗衫] }\end{array}$ & $\begin{array}{c}\text { Jeonghae } \\
\text { Jinchan Uigwe } \\
(1887)\end{array}$ \\
\hline 1892 & $\begin{array}{l}\text { Yeonbaekbokjimu, } \\
\text { Jesuchang, } \\
\text { Choehwamu }\end{array}$ & $\begin{array}{l}\text { Yellow robe } \\
\text { [黃綃單衫] }\end{array}$ & $\begin{array}{c}\text { Red skirt with a blue } \\
\text { under skirt } \\
\text { [裏藍色裳表紅 綃裳] }\end{array}$ & $\begin{array}{c}\text { Embroidered red } \\
\text { belt[紅緞金鏤繡帶] }\end{array}$ & $\begin{array}{c}\text { Flower } \\
\text { headdress } \\
\text { [花冠] }\end{array}$ & $\begin{array}{c}\text { Greenshoes } \\
\text { [草綠鞋] }\end{array}$ & $\begin{array}{l}\text { Five-colored } \\
\text { Hansam } \\
\text { [五色汗衫] }\end{array}$ & $\begin{array}{c}\text { Imjin } \\
\text { Jinchan Uigwe } \\
(1892)\end{array}$ \\
\hline $1901^{\circ}$ & $\begin{array}{c}\text { Jangsengboyeonjimu, } \\
\text { Jesuchang }\end{array}$ & $\begin{array}{c}\text { Yellow robe } \\
\text { [黃綃衫] }\end{array}$ & $\begin{array}{l}\text { Red skirt } \\
\text { [紅綃裳] }\end{array}$ & $\begin{array}{c}\text { Embroidered red } \\
\text { belt[紅繡帶] }\end{array}$ & $\begin{array}{c}\text { Flower } \\
\text { headdress } \\
\text { [花冠] }\end{array}$ & & $\begin{array}{l}\text { Five-colored } \\
\text { Hansam } \\
\text { [五色汗衫] }\end{array}$ & $\begin{array}{c}\text { Sinchuk } \\
\text { Jinyeondo(1901) }\end{array}$ \\
\hline 1902 & $\begin{array}{c}\text { Yeonbaekbokjimu, } \\
\text { Jesuchang, } \\
\text { Choehwamu }\end{array}$ & $\begin{array}{c}\text { Yellow robe } \\
\text { [黃綃單衫] } \\
\text { (or possible to } \\
\text { wear green robe } \\
\text { [綠綃單衫]) }\end{array}$ & $\begin{array}{c}\text { Red skirt with a blue } \\
\text { under skirt } \\
\text { [裏藍色裳表紅 綃裳] }\end{array}$ & $\begin{array}{c}\text { Embroidered red } \\
\text { belt } \\
\text { [紅緞金鏤紴帶 }]\end{array}$ & $\begin{array}{c}\text { Flower } \\
\text { headdress } \\
\text { [花冠] }\end{array}$ & $\begin{array}{c}\text { Greenshoes } \\
\text { [草綠鞋] }\end{array}$ & $\begin{array}{l}\text { Five-colored } \\
\text { Hansam } \\
\text { [五色汗衫] }\end{array}$ & $\begin{array}{r}\text { Imin } \\
\text { Jinyeon } \\
\text { Uigwe } \\
(1902)\end{array}$ \\
\hline
\end{tabular}


1901년의 최화무 여령 복색이 녹색이었을지 여부는 확실치 않 다. 최화무 복식을 시기별로 정리하면 Table 4와 같다.

장생보연지무, 연백복지무, 제수창, 최화무 4 개 정재를 종합 하여 무동 복식과 여령 복식의 변화를 연대순으로 정리하면 Table 5, Table 6과 같다.

\section{4. 장생보연지무, 연백복지무, 제수창, 최화무 복식의 배색}

\section{1. 오행의 상생상극 관계와 색채}

고대의 동양인들은 우주의 많은 개념과 존재를 다섯 가지 기 본 요소와 연관시켜 생각해 왔다, 오행상생설이란 하나의 원기 가 다른 원기를 생성하는 것으로, 오행상극설은 하나의 원기가 다른 원기를 상극하는 것으로 설명하는 사상 체계이다(Nam \& $\mathrm{Kim}, 2006)$ 오행은 서로 상생하여 부족한 것을 보충하거나, 서 로 상극하여 넘치는 것을 조절하여 조화의 묘를 이루게 된다 (Mun, 1973). 고대로부터 동양에서 가장 기본으로 인식되어 온 색은 적, 청, 황, 백, 흑의 다섯 가지 색이었다. 이들 다섯 가 지 색은 5 가지 바른 색으로서 오정색(五正色), 혹은 5 가지 방 위를 나타내는 색으로서 오방색(五方色)이라 불리기도 했다.

『규합총서』(Yi, 1975) 염색제법 채색에 관한 기록을 토대로 오정색(오방색)의 상생 상극 관계를 정리해보면, 오정색(오방색) 의 상생 관계는 “목생화, 화생토, 토생금, 금생수, 수생목"의 상 생 방향으로 각 요소에 해당하는 색을 대입함으로써, 상극 관 계는 “금극목, 목극토, 토극수, 수극화, 화극금”의 상극 방향으 로 각 요소에 해당하는 색을 대입함으로써 알 수 있다. 그런데 오정색이 합성되어 다시 오간색이 만들어지는데, 이 역시 상생 의 방향 혹은 상극의 방향으로 만들어질 수 있다. 『규합총서』 에 의하면 상생의 방향으로 합성된 오간색과 상극의 방향으로 합성된 오간색은 그 종류가 다른데, 상생의 방향으로 합성된 오 간색은 “정(靘, 짙은 보라), 훈(緟, 주황), 규(硅, 연두록), 불 (䊀, 재빛), 암(黯, 천청색) 또는 참(黲, 민색)”이며, 상극의 방향으로 합성된 오간색은 “벽(碧, 연남), 녹(綠, 연초록), 유 (駛, 유록), 자(紫, 자적), 홍(紅, 분홍)"이다. 이를 알기 쉽게 그림으로 정리하면 Fig. 26, Fig. 27과 같다.

상극의 방향으로 합성된 오간색의 합성 과정 및 상호 관계
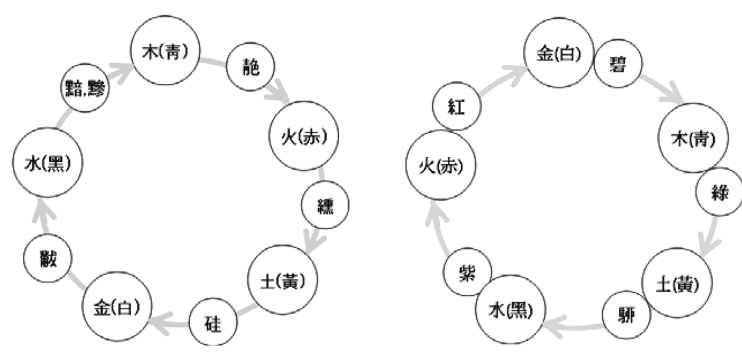

Fig. 26. Circle of the mutual generation[相生]

Fig. 27. Circle of the mutual overcoming[相攰]
에 대해서는 『禮記(Liji)』(1998) 옥조 권29 '의정색상간색(衣正 色裳間色)'의 소(疏)에 상세히 기록되어 있다. 이 기록에 의하 면 “바른 것을 일컬어 청, 적, 황, 백, 흑 오방정색이라 한다. 바 르지 않은 것은 오방간색인데 녹, 홍, 벽, 자, 유황(䭹黄)이 이것 이다. 청(靑)은 동방 정색이며, 녹색(綠色)은 동방 간색이다. 동은 목이 되고, 목색은 청이다. 목은 토를 이기고, 토황(土黃)을 아울 러 이김으로써 간색 혹은 녹색, 즉. 청황색이 된다. 주(朱)는 남방 정색이며, 홍(紅)은 남방 간색이다. 남은 화가 되며, 화적(火赤)은 금을 이긴다. 금은 백인 고로 홍색, 즉 적백색이다. 백(白)은 서 방 정색이며, 벽(碧)은 서방 간색이다. 서는 금이 되며, 금백은 목을 이기는 고로 벽색, 즉 청백색이다. 흑(黑)은 북방 정색이 며, 자(紫)는 북방 간색이다. 북방은 수이고, 수의 색은 흑이다. 수는 화를 이긴다. 화는 적인 고로 자색, 즉 적흑색이다. 황(黄) 은 중앙 정색이며, 유황(駠黃)은 중앙 간색이다. 중앙은 토가 되며, 토는 수를 이긴다. 수는 흑인 고로 유황의 색, 즉 황흑색 이다.”라고 되어 있다.

이 기록을 토대로 볼 때, 녹, 홍, 벽, 자, 유는 비록 간색이 지만 그 위치가 정색들의 정 가운데에 있기 보다는 이기는 색 가까이에 위치해 있는 것으로 이해될 수 있다(Fig. 27). 이는 녹색을 동방 간색으로, 홍색을 남방 간색으로, 벽색을 서방 간 색으로, 자색을 북방 간색으로, 유황색을 중앙 간색으로 상정한 데서도 미루어 짐작할 수 있다. 따라서 상생 및 상극 관계를 논할 때, 벽색은 백색으로, 녹색은 청색으로, 유록은 황색으로, 자적은 흑색으로, 홍색은 적색의 자리에 의탁하여 이해하는 것 이 가능하다. 본 연구에서 간색의 상생 상극 관계는 이러한 방 식에 의해 분석되었다. 이는 곧 달리 말하면, 전통 사회에서 오 정색을 쓰기 어려운 경우, 백색 대신에 벽색을, 청색 대신에 녹 색을, 황색 대신에 유황색을, 흑색 대신에 자색을, 적색 대신에 홍색을 사용하는 것이 가능했음을 시사하는 것이다.

\section{2. 무동 및 여령 복식의 배색}

4.2.1. 무동 복식의 배색 관계

오행의 상생상극관계에 기초하여 장생보연지무, 연백복지무, 제수창, 최화무 무동 복식의 배색 관계를 분석한 결과는 Table 7에 정리된 바와 같다. 상하 배색에서는 '홍포-남상'처럼 상생 의 배색이 보였으며, 표리 배색에서는 '홍포-백중단', '남포-백 중단', '홍의-백중단'과 같이 모두 상극의 배색이 나타났다. 전 체와 부분의 배색에서는 ‘홍포-남대', '백중단-흑선', '남포-홍대', '남상-흑선'과 같이 모두 상생의 배색이 나타났다. 상하 배색과 전체와 부분의 배색에서 모두 상생의 관계를 보이고, 표리 배 색에서는 모두 상극의 관계가 나타난 것은, 이면보다는 표면에 드러나는 복식의 배색 관계를 중시하여 이를 모두 상생의 관계 로 배치한 결과로 이해될 수 있다.

\subsection{2. 여령 복식의 배색 관계}

오행의 상생상극관계에 기초하여 장생보연지무, 연백복지무, 제수창, 최화무 여령 복식의 배색 관계를 분석한 결과는 Table 
Table 7. Color arrangement of the boy dancers' garments

\begin{tabular}{|c|c|c|c|}
\hline Court dance & Top-bottom & Outer-inner & Total-part \\
\hline $\begin{array}{l}\text { Jangsaengboyeonjimu(1829) } \\
\text { Yeonbaekbokjimu(wonmu(元舞), 1829) } \\
\text { Jesuchang(1829) } \\
\text { Choehwamu(1829) }\end{array}$ & & $\begin{array}{c}\mathrm{MO}^{* *}: \text { Red robe[紅袍] and white under } \\
\text { garment[白中單] }\end{array}$ & $\begin{array}{c}\mathrm{MG}^{*}: \text { Red robe[紅袍] and blue belt[藍帶] } \\
\mathrm{MG}^{*} \text { : Black-trimmed white under garment } \\
\text { [白質黑線中單衣] }\end{array}$ \\
\hline $\begin{array}{l}\text { Yeonbaekbokjimu(Seonmo(仙母), } \\
\text { Jukganja(竹竿子), 1829) }\end{array}$ & & $\begin{array}{c}\mathrm{MO}^{* *}: \text { Blue robe[藍袍] and white under } \\
\text { garment[白中單] }\end{array}$ & $\begin{array}{c}\mathrm{MG}^{*} \text { : Blue robe[藍袍] and red belt[紅帶] } \\
\mathrm{MG}^{*} \text { : Black-trimmed white under garment } \\
\text { [白質黑線中單衣] }\end{array}$ \\
\hline Choehwamu(1828) & $\begin{array}{c}\mathrm{MG}^{*}: \text { Red robe } \\
\text { [紅羅袍] and blue } \\
\text { skirt[藍裳] }\end{array}$ & $\begin{array}{c}\mathrm{MO}^{* *}: \text { Red robe[紅羅袍] and white } \\
\text { under garment[白中單] }\end{array}$ & $\begin{array}{c}\mathrm{MG}^{*} \text { : Black-trimmed blue skirt[藍質黑線裳] } \\
\mathrm{MG}^{*} \text { : Black-trimmed white under garment } \\
\text { [白質黑線中單衣] }\end{array}$ \\
\hline $\begin{array}{l}\text { Jangsaengboyeonjimu(1892, 1902) } \\
\text { Yeonbaekbokjimu(1892, 1902) } \\
\text { Jesuchang(1892, 1902) }\end{array}$ & & $\begin{array}{c}\mathrm{MO}^{* *}: \text { Red jacket[紅衣] and white under } \\
\text { garment[白中單] }\end{array}$ & \\
\hline
\end{tabular}

*MG: Mutual generation[相生], ${ }^{* *}$ MO: Mutual overcoming[相剋]

Table 8. Color arrangement of the female dancers' garments

\begin{tabular}{|c|c|c|c|c|}
\hline Court dance & Top-bottom & Outer-inner & Total-part & Part-part (Five-colored Hansam[五色汗衫]) \\
\hline $\begin{array}{l}\text { Jangsaengboyeonjimu } \\
\text { Yeonbaekbokjimu } \\
\text { Jesuchang } \\
\text { Choehwamu }\end{array}$ & $\begin{array}{c}\mathrm{MG}^{*}: \text { Yellow robe } \\
\text { [黃綃衫] and red skirt } \\
\text { [紅裳] }\end{array}$ & $\begin{array}{l}\mathrm{MG}^{*}: \text { Red skirt[紅裳] } \\
\text { and blue skirt[藍裳] }\end{array}$ & $\begin{array}{c}\mathrm{MG}^{*}: \text { Yellow robe } \\
\text { [黃綃衫] and red belt } \\
\text { [紅繡帶] }\end{array}$ & $\begin{array}{l}\text { Red-blue-purple-yellow-white } \\
\text { Purple-green-yellow-red-blue } \\
\text { White-red-green-yellow-blue }\end{array}$ \\
\hline
\end{tabular}

*MG: Mutual generation[相生]

8에 정리된 바와 같다. 상하 배색에서는 '황삼-홍상'과 같이 상 생의 배색이 보였으며, 표리 배색에서는 '홍상-남상'과 같이 상 생의 배색이 보였다. 전체와 부분의 배색에서도 '황삼-홍대'와 같이 상생의 배색이었다. 무동 복식의 배색에서 표리 배색이 모 두 상극 관계였던 것과는 달리 여령 복식의 배색에서는 표리 배색도 상생 관계인 점이 특이하다.

\subsection{3. 여령 한삼의 배색 관계}

여령 복식에는 오색 한삼이 포함되어 있어서 오색 한삼 내 에서 부분과 부분의 배색 관계를 분석하는 것이 가능했다. 장 생보연지무, 연백복지무 여령 오색 한삼의 배색 순서를 살펴보 면, 손목부위에서 바깥을 향해 '적-청-자-황-백'의 순서인 경우 (National Museum of Korea, 2010: 무신진찬도, 유물번호 본 13243), '자-녹-황-홍-청'의 순서인 경우(National Museum of Korea, 2010: 무신진찬도, 유물번호 동2649), ‘백-홍-녹-황-청’의 순서인 경우(National Museum of Korea, 2010: 정해진찬도, 유물번호 덕6184) 등이 있었다. 오색의 종류 및 배치 순서가 일정하지 않았으며, 정색과 간색을 혼합하여 사용했음을 알 수 있다.

오정색 중에서 한삼에 사용되지 않은 색은 흑색이었으며, 흑 색 대신에 간색인 자색과 녹색 등이 사용되고 있었다. 이러한 결과를 모든 정재 여령 복식에 사용된 오색 한삼으로 확대 해 석할 수는 없으나, 조선 후기에 오색으로 대표된 색이 어떤 종 류의 색들이었는지에 관해서는 의미 있는 결과로 생각된다.

상생상극관계에 의거하여 세 종류 한삼의 배색을 분석해 보
면, '적-청-자-황-백' 한삼은 3 개의 상생(적-청, 청-자, 황-백), 1 개의 상극(자-황) 관계를 보였으며, '자-녹-황-홍-청' 한삼 역시 3 개의 상생(자-녹, 황-홍, 홍-청), 1 개의 상극(녹-황) 관계를 보여 상생 배색이 상극 배색보다 많은 경향을 보였다. 그러나 '백-홍 -녹-황-청, 한삼의 경우에는 1 개의 상생(홍-녹), 3 개의 상극(백홍, 녹-황, 황-청) 관계를 보이고 있었다.

\section{5. 결 론}

본 연구는 장생보연지무, 연백복지무, 제수창, 최화무 무동 및 여령 복식의 종류 및 형태, 변화 특징을 살펴보고, 이들 복 식에 사용된 색채의 배색 특성을 고찰한 연구이다. 연구의 결 과이자, 본 연구의 결론은 다음과 같다.

첫째, 장생보연지무, 연백복지무, 제수창, 최화무 무동의 복 식은 춤의 종류, 무동의 역할, 시간의 변화 등에 따라 복식의 종류가 조금씩 다르게 나타났다. 4 개 정재 전부에서 공통적으 로 홍포와 백질흑선중단의가 사용되었다. 그러나 연백복지무에 서는 원무 무동과 선모 및 죽간자 무동의 옷이 달라서, 원무 무 동은 홍포를 입었으나 선모 및 죽간자 무동은 남포를 입었다. 홍 포에는 각건, 남야대, 흑화를 입었으며, 남포에는 복두, 홍야대, 흑화를 썼다. 장생보연지무, 연백복지무, 제수창에서 무동은 주 로 홍포를 입었지만, 후대로 오면서 일반 무동의 복식인 홍화 주의를 입게 된다. 순조 29년(1829)에는 홍포, 백질흑선중단의, 남 야대, 각건, 흑화를 사용하던 제도가 고종 29년(1892)에는 홍화주 의, 홍화주상, 백단의, 홍남야대, 화관으로 바뀌게 된 것이다. 무 
동의 홍포는 여령의 황초삼과 달리 대수 단령포 형태였다.

둘째, 장생보연지무, 연백복지무, 제수창, 최화무 여령의 복 식은 모두 화관, 황초삼, 홍초상, 수대를 기본으로 하는 일반 여령의 복식을 따랐던 것으로 보인다. 19 세기 일반 여령의 복 식 품목의 종류는 큰 변화가 없었으나, 시간의 변화에 따라 약 간의 형태 및 장식의 차이를 보였다. 여령의 화관이 규모가 많 이 축소되어 족두리 모양으로 변했으며, 황초삼의 곡선 배래가 완화되었다. 홍초상은 옆선이 곡선적이고 폭이 좁은 형태에서 폭이 넓은 일상복 치마 형태로 변했으며, 수대의 장식 위치와 문양이 바뀐 것으로 나타났다.

셋째, 오행의 상생상극관계에 의거하여 장생보연지무, 연백 복지무, 제수창, 최화무 복식의 배색 관계를 살펴본 결과, 무동 및 여령 복식 전반에 걸쳐 상생의 배색이 많이 사용된 것으로 나타났다. 무동 복식의 경우, 상하 배색과 전체와 부분의 배색 에서 모두 상생의 관계를 보였으며, 표리 배색에서는 모두 상 극의 관계를 보였다. 여령 복식의 경우에는, 상하 배색, 표리 배색, 전체와 부분의 배색에서 모두 상생 관계를 보였으며, 오 색 한삼의 부분과 부분 배색에서는 상생과 상극 관계가 모두 공존하고 있었다. 정재 복식의 배색관계는 이면보다는 표면에 드러나는 복식의 배색 관계를 중시하여 상생의 관계로 배치하 는 경향이 있었으며, 색동과 같이 작은 부분들이 연결될 때는 상생 상극의 관계보다는 다채로운 색을 추구하는 것에 더욱 주 안점을 두었음을 알 수 있었다.

\section{References}

高宗王寅進宴儀軌 [Gojong Imin Jinyeon Uigwe] (1902). Seoul National University Gyujanggak, Uigwe Digital Archive, Gyu14494. Retrieved April 19, 2013, from http://e-kyujanggak. snu.ac.kr

高宗壬辰進䱋儀軌 [Gojong Imjin Jinchan Uigwe] (1892). Seoul National University Gyujanggak, Uigwe Digital Archive, Gyul4428. Retrieved April 19, 2013, from http://e-kyujanggak. snu.ac.kr

高宗丁亥進饌儀轨 [Gojong Jeonghae Jinchan Uigwe] (1887). Seoul National University Gyujanggak, Uigwe Digital Archive, Gyu14405. Retrieved April 19, 2013, from http://e-kyujanggak. snu.ac.kr

Heo, Y. I. (2005). 한국 전통무용의 변천과 전승 [Transformation and transmission of the Korean traditional dances]. Seoul: Bogosa.

憲宗戊申進错儀軌 [Heonjong Musin Jinchan Uigwe] (1848). Seoul National University Gyujanggak, Uigwe Digital Archive, Gyu14372. Retrieved April 19, 2013, from http://e-kyujanggak. snu.ac.kr

Kim, G. S. (2005). 대한제국의 진연복식에 관한 연구 [A study on the royal banquet garment on the Korean Empire]. In Hangukhak Jungang Yeonguwon (Eds.), 조선후기 궁중연향문화, 3 [Royal banquet culture in the late Joseon dynasty, vol. 3] (pp. 236-321). Seoul: Minsokwon.

Kim, J. S. (2004). 헌종무신진찬의궤 해제 [Commentary on the
Heonjong Musin Jinchan Uigwe]. In Hanguk Yesul Jonghap Hakkyo Jeontong Yesulwon (Eds.), 헌종무신진찬의궤, 1 [Heonjong Musin Jinchan Uigwe, vol. 1]. Seoul: Minsokwon.

Kim, J. S. (2007). 순조기축진찬의궤 해제 [Commentary on the Sunjo Gichuk Jinchan Uigwe]. In B. S. Song \& J. S. Kim (Eds.), 순조기축진찬의궤, 1 [Sunjo Gichuk Jinchan Uigwe, vol. 1] (pp. 11-21). Seoul: Minsokwon.

Lee, H. G. \& Son, G. S. (2010a). 한국궁중무용총서, 10: 박접무, 연 백복지무, 장생보연지무, 춘앵전 [A series of Korean court dances, vol 10: Bakjeobmu, Yeonbaekbokjimu, Jangsaengboyeon jimu, and Chunaengjeon]. Seoul: Bogosa.

Lee, H. G., \& Son, G. S. (2010b). 한국궁중무용총서, 9: 경풍도, 무산향, 첨수무, 심향춘, 제수창, 가인전목단 [A series of Korean court dances, vol 9: Gyeongpungdo, Musanhyang, Cheomsumu, Simhyangchun, Jesuchang, and Gainjeonmukdan]. Seoul: Bogosa.

Lee, H. G. \& Son, G. S. (2010c). 한국궁중무용총서, 11: 헌천화, 만수무, 최화무, 고구려무, 선유락 [A series of Korean court dances, vol 11: Heoncheonhwa, Mansumu, Choihwamu, Goguryeomu, Seonurak]. Seoul: Bogosa.

僼記 [Liji] (1998). (Seongkyungwan University Daedong Munhwa Yeonguwon, Reprint). Seoul: Seongkyungwan University Daedong Munhwa Yeonguwon.

Mun, G. Y. (1973). 해동철학체계 [A system of Haedong philosophy]. Seoul: Sangdang Chulpansa.

Nam, H. S. (1995). A study on the ritual dancing suit in the Korean royal court. Unpublished doctoral dissertation, Yeongnam University, Daegu.

Nam, H. S. (2000). A Study on the colors of court dancing suits in the latter period of Chosun dynasty: Centering around dances Yukhwadae, Musanhyang, Choonagengjeon. Journal of the Korean Society of Costume, 50(4), 73-87.

Nam, H. S. (2003). A Study on the court dancing suits in the latter period of Chosun dynasty: Centering around dances Gainjeonmokdan, Goguryeomu, Gongmakmu, Mansumu. Journal of the Korea Fashion \& Costume Design Association, 5(1), 89-96.

Nam, H. S., \& Kim, S. Y. (2005). A Study on the colors of dancing suits in Bongraewoi, Hyangbalmu and Hakmu. Journal of the Korean Society of Costume, 55(6) extened version, 51-61.

Nam, H. S., \& Kim, S. Y. (2006). A study on the colors of dancing suits in Bosangmu, Cheomsumu, and Heoncheonhwa. Journal of the Korean Society for Clothing Industry, 8(2), 168-176.

National Gugak Center (1981). 時用舞譄; 呈才舞圖笳記 [Siyong Mubo; Jeongjae Mudo Holgi]. Seoul: National Gugak Center.

National Museum of Korea (2010). 조선시대 궁중행사도, I [Joseon paintings of court ceremonies, vol. 1]. Seoul: Natinoal Museum of Korea.

National Museum of Korea (2012). 조선시대 궁중행사도, 3 [Joseon paintings of court ceremonies, vol. 3]. Seoul: Natinoal Museum of Korea.

Seong, G. L. (1995). 한국전통무용 [Korean traditional dances]. Seoul: Iljisa.

純祖已丑進筫儀軌 [Sunjo Gichuk Jinchan Uigwe] (1829). Seoul National University Gyujanggak, Uigwe Digital Archive, Gyu14370. Retrieved April 19, 2013, from http://e-kyujanggak. snu.ac.kr

純祖戊子進䨖儀軌 [Sunjo Muja Jinjak Uigwe] (1828). Seoul National 
University Gyujanggak, Uigwe Digital Archive, Gyul4364. Retrieved April 19, 2013, from http://e-kyujanggak.snu.ac.kr

Yi, B. (1975). 규합총서 [Gyuhap Chongseo]. (Y. W. Jung, Trans.). Seoul: Bojinjae. (Original work published 1759)
(Received 27 June 2013; 1st Revised 7 August 2013; 2nd Revised 26 August 2013; 3rd Revised 26 August 2013; Accepted 1 November 2013)

Copyright (C) The Society of Fashion and Textile Industry. 2013. This is an open access article distributed under the terms and conditions of the Creative Commons Attribution Non-Commercial license (http://creativecommons.org/licenses/by-nc/3.0/), which permits unrestricted non-commercial use, distribution, and reproduction in any medium, provided the original work is properly cited. 